\title{
Efikasi Herbisida Campuran Atrazin Dan Mesotrion Untuk Mengendalikan Gulma Pada Budidaya Tanaman Jagung ( Zea Mays L.)
}

\section{Efficacy Of Combination Atrazine And Mesotrione Herbicide To Control Weeds In Maize (Zea Mays L.)}

\author{
Dera Fungky Ellezandi ${ }^{1}$, Dad R.J. Sembodo ${ }^{2}$, dan Herawati Hamim ${ }^{3}$ \\ ${ }^{1}$ Mahasiswa Jurusan Agroteknologi, FP, Unila \\ ${ }^{2}$ Dosen Jurusan Agroteknologi FP, Unila \\ Jl. Prof. Dr. Soemantri Brojonegoro No. 1 Bandar Lampung 35145 \\ Email :dera_fungky@yahoo.com
}

\section{ABSTRACT}

\begin{abstract}
Maize (Zea mays $L$ ) is the most important food crops in the world beside rice and wheat. Weeds are one factor cause decrease productivity of maize. The objectives of this research were to know of dose combination atrazine and mesotrione herbicide to control the weed in maize field and how was the atrazine and mesotrione effect to maize. The research was conducted in Natar, South Lampung and Weeds Laboratory Faculty of Agriculture, University of Lampung, from December 2014 to April 2015. The experiment was arranged in Completely Randomized Block Design (CRBD) with six treatments and four replications. The treatments are combination atrazine and mesotrion herbicide rates at 500+50; 750+75; $1000+100 ; 1250+125 ;$ and $1500+150 \mathrm{~g} \mathrm{ha} a^{-1}$, mechanical weeding, and control. Homogenity of variance was tested by Bartlett test and additivitty tested by Tukey's test, the comparison of mean were tested by Least Significant Difference (LSD) test at 5\% level. The result showed that (1) Atrazine and mesotrione herbicide at 500+50 until 1500+150 g ha could suppress total, sedges, Cyperus rotundus and Celosia argenthea weed at 3 Weeks After Treatment (WAT), whereas at 6 WAT couldn't suppress weeds. (2) Atrazine and mesotrione herbicide at 500+50 until $1500+150 \mathrm{~g}$ ha could suppress broadleaves, Richardia brasiliensis and Commelina benghalensis weeds until 6 WAT. (3) Atrazine and mesotrione herbicide at 500+50 until 1500+150 g ha couldn't suppress grasses and Rottboellia exaltata weed until 6 WAT (4) Atrazine and mesotrione herbicide does not affect the growth and production of maize.
\end{abstract}

Key words: Weed, Efficacy, Atrazine, Mesotrione, Maize

Diterima: 15 Oktober 2015, disetujui 19 Desember 2015

\section{PENDAHULUAN}

Jagung (Zea mays L.) adalah salah satu tanaman pangan penghasil karbohidrat yang terpenting di dunia, selain gandum dan padi. Bagi penduduk Amerika Tengah dan Selatan, bulir jagung adalah pangan pokok, sebagaimana bagi sebagian penduduk Afrika dan beberapa daerah di Indonesia (Krisnamurthi, 2010). Di masa kini, jagung menjadi komponen penting pakan ternak. Penggunaan lainnya adalah sebagai sumber minyak pangan dan bahan dasar tepung maizena. Berbagai produk turunan hasil jagung menjadi bahan baku berbagai produk industri, seperti bioenergi, industri kimia, kosmetika, dan farmasi (Solfiyani, 2013). Produksi jagung di Indonesia mengalami peningkatan, pada tahun 2012 sebesar 19,37 ton, sedangkan pada 

tahun sebelumnya hanya sebesar 17,64 juta ton. Tingginya kebutuhan jagung di Indonesia menyebabkan Indonesia masih melakukan Impor dari luar negeri ( Badan Pusat statistik 2013 dalam Mustajab 2015).

Salah satu penyebab rendahnya produksi jagung adalah kehadiran gulma pada lahan budidaya. Keberadaan gulma di sekitar tanaman budidaya dapat menyebakan kerugian yang besar walaupun berlangsung secara perlahan (Bilman, 2001). Ada berbagai teknik pengendalian gulma, yaitu secara fisik, mekanis, kultur teknis dan kimiawi. Pada saat ini tidak sedikit petani yang mengendalikan gulma secara kimiawi, yaitu menggunakan herbisida. Mesotrion adalah jenis herbisida baru dalam kelompok triketon dan efektif terhadap spesies yang resisten terhadap herbisida triazin dan herbisida penghambat ALS (Acetolactate synthase). Secara umum mesotrion bertindak sebagai penghambat pigmen (Ismail \& Kalithasan 1999, Hess 2000, Martin, 2000, Read \& Cobb 2000, Vencill et al. 2002) dalam Hasanudin (2013).

Penggunaan herbisida memberikan harapan yang baik, tetapi mutlak diperlukan pengetahuan dasar yang memadai tentang teknik pengendalian gulma secara kimiawi. Termasuk di antaranya penentuan jenis herbisida, cara pemakaian, ketepatan dosis, dan waktu aplikasi. Tingkat dosis aplikasi menentukan efektivitas penggunaan herbisida untuk mengendalikan gulma, sekaligus mempengaruhi mempengaruhi efisiensi pengendalian secara ekonomi (Djojosumarto, 2000 dalam Girsang 2005).

\section{METODE}

Penelitian dilakukan di Kebun Percobaan Haji Mena, Kecamatan Natar, Kabupaten Lampung Selatan dengan jenis tanah ultisol dan di Laboratorium Gulma Fakultas Pertanian Universitas Lampung dari bulan Desember 2014 hingga April 2015. Alat yang digunakan adalah timbangan Digital, gelas ukur, knapsack sprayer, ember plastik, pipet, ruber bulb, oven, sabit, moisture tester, kantong plastik, patok bambu, meteran, cangkul, dan amplop kertas. Bahan yang digunakan adalah benih jagung hibrida piooner 27, pupuk NPK (Phonska) dan urea $100 \mathrm{~kg} / \mathrm{ha}$, dan herbisida Lares $550 \mathrm{SC}$ dengan bahan aktif ganda (Premix) dengan kandungan atrazin $500 \mathrm{~g} / \mathrm{l}$ dan mesotrion $50 \mathrm{~g} / \mathrm{l}$. .

Perlakuan disusun dengan Rancangan Acak Kelompok (RAK), 7 perlakuan (herbisida campuran Atrazin dan Mesotrion dengan dosis 500+50; 750+75; 1000+100; 1250+125; dan 1500+150 g /ha serta penyiangan manual dan kontrol (tanpa pengendalian gulma) dengan 4 ulangan. Untuk menguji homogenitas ragam digunakan uji Bartlett dan additifitas data diuji dengan menggunakan uji Tukey. Uji perbedaan nilai tengah perlakuan akan diuji dengan uji Beda Nyata Terkecil (BNT) pada taraf 5\%. Setiap plot berukuran $4 \mathrm{~m}$ x $7 \mathrm{~m}$. Pada setiap plot terdapat 5 baris tanaman jagung dengan jarak $0.8 \mathrm{~m}$. Volume semprot yang digunakan $500 \mathrm{~L} / \mathrm{ha}$.

Variabel pengamatan meliputi bobot kering gulma total, bobot kering gulma golongan daun lebar, bobot kering gulma golongan rumput, fitotoksisitas, dan pipilan kering jagung.

\section{HASIL DAN PEMBAHASAN}

\section{Bobot Kering Gulma Total}

Pada 3 minggu setelah aplikasi (MSA ) bobot kering gulma total pada Tabel 1 menunjukkan bahwa terjadi penekanan pertumbuhan gulma oleh herbisida atrazin dan mesotrion pada gulma yang tumbuh di petak perlakuan. Hal ini berarti tidak terjadi perbedaan penekanan pertumbuhan gulma pada semua dosis perlakuan herbisida, sedangkan pada 6 MSA keseluruhan perlakuan tidak dapat mengendalikan gulma total, hal ini diduga karena pada 6 MSA semua dosis herbisida hanya mampu menekan pertumbuhan gulma golongan daun lebar, sehingga gulma golongan teki dan rumput tidak tertekan. 
Jurnal Penelitian Pertanian Terapan

Syngenta 2010 dalam Hasanudin 2013 menyatakan bahwa beberapa herbisida yang diformulasikan untuk pengendalian gulma pada tanaman jagung, yaitu herbisida berbahan aktif atrazin dan mesotrion. Kedua herbisida ini memiliki persistensi yang cukup singkat.

Tabel 1. Bobot kering gulma total akibat perlakuan Herbisida Atrazin+ Mesotrion

\begin{tabular}{|c|c|c|c|c|c|}
\hline Perlakuan & Dosis (g/ha) & 3 MSA & $. \mid x, n E x$ & 6 MSA &.$|x| n E x$ \\
\hline & & \multicolumn{4}{|c|}{$\ldots \ldots \ldots \ldots \ldots \ldots \ldots \ldots\left(\mathrm{g} / 0,5 \mathrm{~m}^{2}\right) \ldots \ldots \ldots \ldots \ldots \ldots \ldots$} \\
\hline Atrazin+Mesotrion & $500+50$ & 17,05 & $3,62 \mathrm{~b}$ & 63,22 & $6,99 \mathrm{ab}$ \\
\hline Atrazin+Mesotrion & $750+75$ & 4,24 & $2,07 \mathrm{~b}$ & 63,57 & $7,20 \mathrm{ab}$ \\
\hline Atrazin+Mesotrion & $1000+100$ & 14,74 & $3,44 b$ & 97,78 & $8,20 \mathrm{ab}$ \\
\hline Atrazin+Mesotrion & $1250+125$ & 5,32 & $2,37 \mathrm{~b}$ & 109,51 & $9,26 \mathrm{ab}$ \\
\hline Atrazin+Mesotrion & $1500+150$ & 8,74 & $2,86 \mathrm{~b}$ & 47,40 & $5,90 \mathrm{ab}$ \\
\hline Mekanis & - & 42,20 & $6,25 \mathrm{a}$ & 5,67 & $2,31 \mathrm{~b}$ \\
\hline Kontrol & - & 38,52 & $6,12 \mathrm{a}$ & 101,13 & $9,76 \mathrm{a}$ \\
\hline BNT & & & 2,29 & & 6,84 \\
\hline
\end{tabular}

Keterangan: Nilai tengah pada setiap kolom yang diikuti huruf yang sama tidak berbeda nyata menurut uji BNT pada $\operatorname{taraf} 5 \%$.

Gambar 1 menunjukan bahwa pada 3 MSA persentase penekanan seluruh perlakuan herbisida atrazin dan mesotrion berkisar 50 hingga $90 \%$, sedangkan pada 6 MSA tingkat penekanan tertinggi pada dosis $1500+150 \mathrm{~g} / \mathrm{ha}$ yaitu sebesar $53 \%$.

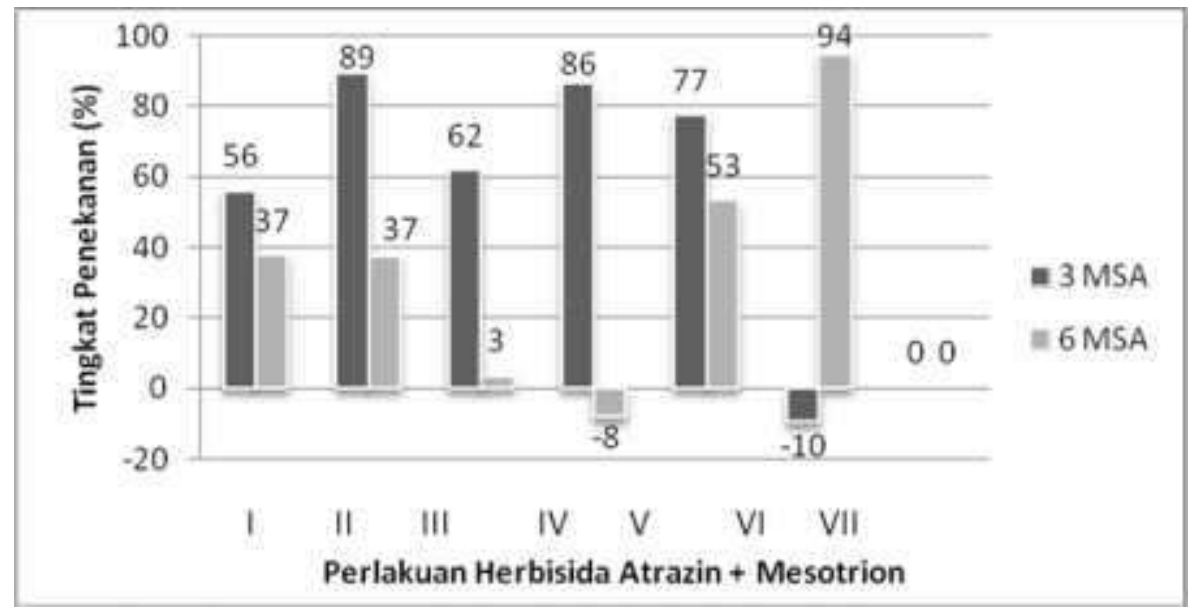

Gambar 1. Tingkat Penekanan Herbisida Atrazin+Mesotrion terhadap Gulma Total

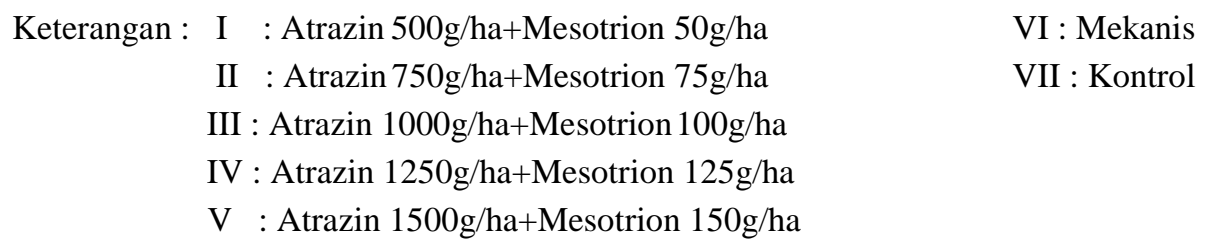

\section{Bobot Kering Gulma Golongan Daun Lebar}

Spesies gulma golongan daun lebar yang terdapat pada petak percobaan antara lain Ricardia brasiliensis, Celosia argenthea, Commelina bengalensis, Cleome rutidosperma, Asystasia gangetica, Ipoema batatas, Comellina difusa, Synedrella nodiflora, Phyllantus niruri, Calopogonium mucunoides, Amaranthus spinosus, Portulaca oleraceae, Ageratum conyzoides, Lindernia procumbens, Borreria alata, 
Dera Fungky Ellezandi dkk: Efikasi Herbisida Campuran Atrazin Dan Mesotrion Untuk Mengendalikan Gulma ...

Euphorbia hirta, Ludwegia hysopifolia, Ipomeia batatas, Mimosa invesa, Oxalis barelieri dan Spigelia anthelmia. Berdasarkan Tabel 2 menunjukkan bahwa keseluruhan perlakuan dapat mengendalikan gulma golongan daun lebar hingga 6 MSA. Hal ini ditunjukkan dengan masih rendahnya bobot kering gulma yang diberi perlakuan herbisida dari dosis paling rendah hingga dosis paling tinggi. Ditambahkan oleh (Direktorat Jenderal Tanaman Pangan 2010) dalam Hasanudin 2013, herbisida campuran atrazin dan mesotrion dapat mengendalikan gulma berdaun lebar yang diaplikasikan sebelum dan sesudah tumbuh gulma pada tanaman jagung.

Tabel 2. Bobot kering gulma daun lebar akibat perlakuan Herbisida Atrazin + Mesotrion

\begin{tabular}{|c|c|c|c|c|c|}
\hline Perlakuan & Dosis (g/ha) & Asli & $\begin{array}{l}3 \text { MSA } \\
\sqrt{ }(\sqrt{ }(\sqrt{ }(x+0,5)))\end{array}$ & Asli & $\begin{array}{l}6 \text { MSA } \\
\sqrt{ }(\sqrt{ }(x+0,5))\end{array}$ \\
\hline & \multicolumn{5}{|c|}{ 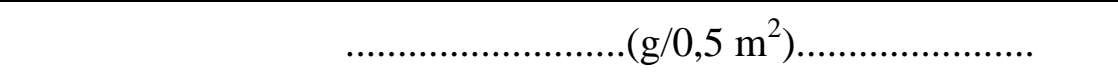 } \\
\hline Atrazin+Mesotrion & $500+50$ & 0,00 & $0,91 \mathrm{~b}$ & 0,96 & $1,07 \mathrm{~b}$ \\
\hline Atrazin+Mesotrion & $750+75$ & 0,00 & $0,91 \mathrm{~b}$ & 0,89 & $1,07 \mathrm{~b}$ \\
\hline Atrazin+Mesotrion & $1000+100$ & 1,31 & $0,99 \mathrm{~b}$ & 0,65 & $1,00 \mathrm{~b}$ \\
\hline Atrazin+Mesotrion & $1250+125$ & 0,00 & $0,91 \mathrm{~b}$ & 0,55 & $0,98 \mathrm{~b}$ \\
\hline Atrazin+Mesotrion & $1500+150$ & 0,00 & $0,91 \mathrm{~b}$ & 1,01 & $1,07 \mathrm{~b}$ \\
\hline Mekanis & - & 21,82 & $1,47 \mathrm{a}$ & 2,55 & $1,26 \mathrm{~b}$ \\
\hline Kontrol & - & 17,13 & $1,40 \mathrm{a}$ & 78,49 & $2,90 \mathrm{a}$ \\
\hline BNT & & & 0,10 & & 0,35 \\
\hline
\end{tabular}

Keterangan : Nilai tengah pada setiap kolom yang diikuti huruf yang sama tidak berbeda nyata menurut uji BNT pada taraf $5 \%$.

Gambar 2 menunjukkan bahwa pada 3 MSA seluruh perlakuan mampu memberikan penekanan terhadap pertumbuhan gulma golongan daun lebar sebesar $100 \%$ kecuali pada dosis $1000+100 \mathrm{~g} / \mathrm{ha}$ yang hanya mampu menekan sebesar 92\%, sedangkan pada 6 MSA tingkat penekanan antar perlakuan sama baik yaitu sebesar $95 \%$.

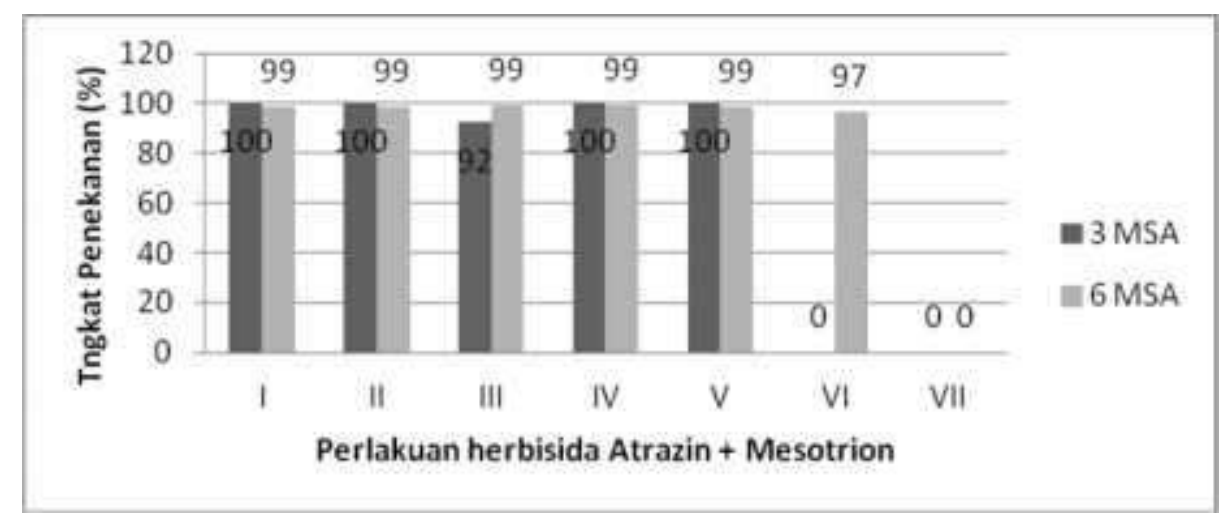

Gambar 2. Tingkat Penekanan Herbisida Atrazin+Mesotrion terhadap Gulma Golongan Daun Lebar

$\begin{array}{rr}\text { Keterangan : I : Atrazin } 500 \mathrm{~g} / \mathrm{ha}+\text { Mesotrion } 50 \mathrm{~g} / \mathrm{ha} & \text { VI }: \text { Mekanis } \\ \text { II }: \text { Atrazin } 750 \mathrm{~g} / \mathrm{ha}+\text { Mesotrion } 75 \mathrm{~g} / \mathrm{ha} & \text { VII }: \text { Kontrol } \\ \text { III : Atrazin } 1000 \mathrm{~g} / \mathrm{ha}+\text { Mesotrion } 100 \mathrm{~g} / \mathrm{ha} & \\ \text { IV : Atrazin } 1250 \mathrm{~g} / \mathrm{ha}+\text { Mesotrion } 125 \mathrm{~g} / \mathrm{ha} & \\ \text { V : Atrazin } 1500 \mathrm{~g} / \mathrm{ha}+\text { Mesotrion } 150 \mathrm{~g} / \mathrm{ha} & \end{array}$


Jurnal Penelitian Pertanian Terapan

\section{Bobot Kering Gulma Golongan Rumput}

Pada keseluruhan petak percobaan, gulma golongan rumput yang dapat ditemukan adalah gulma Rottboellia exaltata, Dactylon teniun, DigItaria ciliaris, Brachiaria mutica, Cyrtococum accrecens, Eleusine indica, Imperata chylindrica, dan Echinochloa colona. Data yang ditampilkan oleh Tabel 3 menunjukkan bahwa keseluruhan perlakuan tidak dapat mengendalikan gulma golongan rumput hingga 6 MSA, Hal ini ditunjukkan dengan tingginya bobot kering gulma yang diberi perlakuan herbisida dari dosis paling rendah hingga dosis paling tinggi.

Tabel 3. Bobot kering gulma rumput akibat perlakuan Herbisida Atrazin + Mesotrion

\begin{tabular}{|c|c|c|c|c|c|}
\hline Perlakuan & Dosis (g/ha) & $3 \mathrm{MSA}$ & \multicolumn{2}{|r|}{6 MSA } & \\
\hline Atrazin+Mesotrion & $500+50$ & 14,44 & $3,18 \mathrm{a}$ & 12,23 & $2,55 \mathrm{a}$ \\
\hline Atrazin+Mesotrion & $750+75$ & 2,91 & $1,73 \mathrm{a}$ & 51,35 & $6,01 \mathrm{a}$ \\
\hline Atrazin+Mesotrion & $1000+100$ & 13,13 & $3,28 \mathrm{a}$ & 96,27 & $7,85 \mathrm{a}$ \\
\hline Atrazin+Mesotrion & $1250+125$ & 3,87 & $1,94 \mathrm{a}$ & 92,69 & $7,53 \mathrm{a}$ \\
\hline Atrazin+Mesotrion & $1500+150$ & 8,55 & $2,76 \mathrm{a}$ & 44,74 & $5,19 \mathrm{a}$ \\
\hline Mekanis & - & 16,35 & $3,00 \mathrm{a}$ & 1,76 & $1,29 \mathrm{a}$ \\
\hline Kontrol & - & 8,05 & $2,65 \mathrm{a}$ & 17,93 & $3,29 \mathrm{a}$ \\
\hline $\mathrm{BNT}$ & & & 2,50 & & 7,03 \\
\hline
\end{tabular}

Keterangan $\quad$ : Nilai tengah pada setiap kolom yang diikuti huruf yang sama tidak berbeda nyata menurut uji BNT pada taraf $5 \%$.

Gambar 3 menunjukkan bahwa pada 3 MSA tingkat penekan tertinggi pada dosis $750+75 \mathrm{~g} / \mathrm{ha}$ yang mampu menekan gulma sebanyak $64 \%$ sedangkan pada dosis $500+50 \mathrm{~g} / \mathrm{ha} ; 1000+100 \mathrm{~g} / \mathrm{ha} ; 1500+150 \mathrm{~g} / \mathrm{ha}$ tidak terjadi penekanan. Pada 6 MSA tingkat penekanan tertinggi pada herbisida atrazin+mesotrion dengan dosis $500+50 \mathrm{~g} / \mathrm{ha}$ yaitu sebesar $32 \%$, sedangkan pada dosis $750+75 \mathrm{~g} / \mathrm{ha} ; 1000+100 \mathrm{~g} / \mathrm{ha} ; 1500+150 \mathrm{~g} / \mathrm{ha}$ tidak terjadi penekanan. Hal ini diduga bahwa pada dosis tersebut hanya mampu mengendalikan gulma golongan daun lebar, sehingga gulma rumput tetap berada di petak perlakuan. Menurut penelitian Hasanudin (2013), dosis herbisida campuran atrazin dan mesotrion yang mampu mengendalikan gulma golongan rumput yaitu sebesar 1,2 1/ha, namun selain di tentukan oleh dosis herbisida, juga ditentukan oleh faktor iklim, seperti kelembaban relatif. Menurut (Wichert dan Talbert (1992) dalam hasanudin (2013)), terdapat peningkatan pengendalian jenis gulma manakala kelembaban relatif meningkat dari $50 \%$ menjadi $85 \%$.

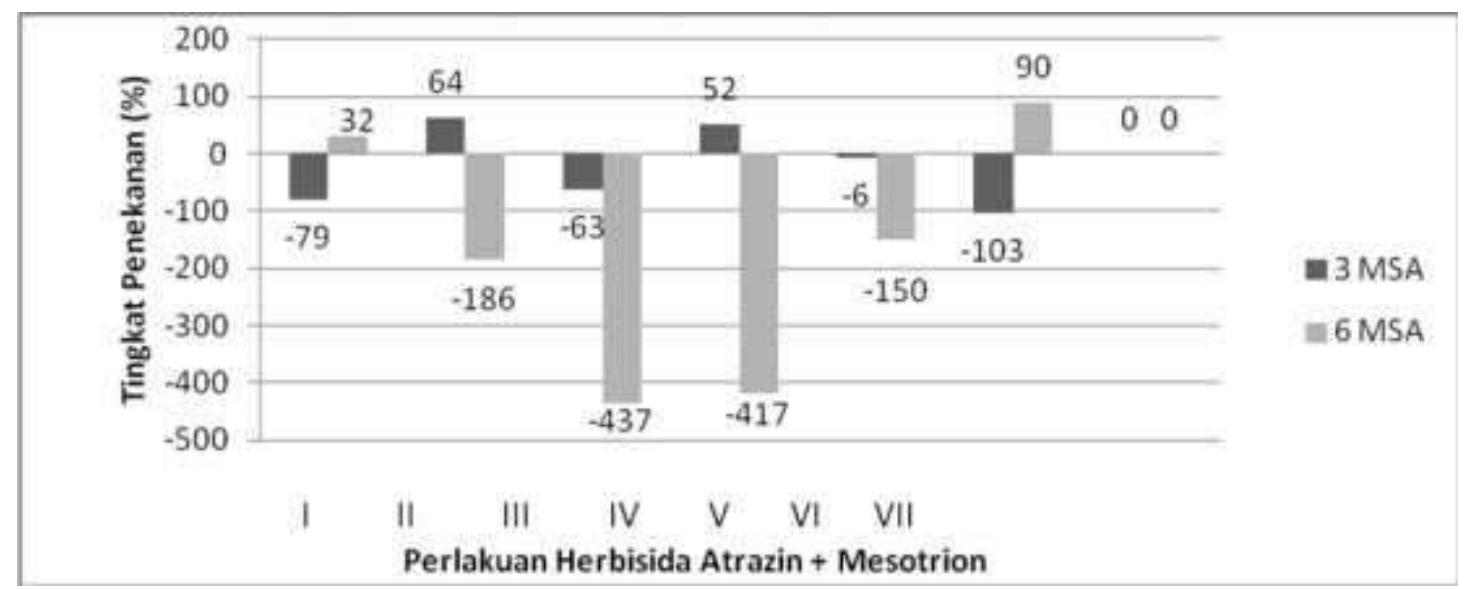

Gambar 3. Tingkat Penekanan Herbisida Atrazin+Mesotrion terhadap Gulma Golongan Rumput 
Dera Fungky Ellezandi dkk: Efikasi Herbisida Campuran Atrazin Dan Mesotrion Untuk Mengendalikan Gulma ...
Keterangan : I : Atrazin 500g/ha+Mesotrion 50g/ha
VI : Mekanis
II : Atrazin $750 \mathrm{~g} / \mathrm{ha}+$ Mesotrion $75 \mathrm{~g} / \mathrm{ha}$
VII : Kontrol
III : Atrazin 1000g/ha+Mesotrion 100g/ha
IV : Atrazin 1250g/ha+Mesotrion $125 \mathrm{~g} / \mathrm{ha}$
$\mathrm{V}$ : Atrazin 1500g/ha+Mesotrion $150 \mathrm{~g} / \mathrm{ha}$

\section{Bobot Kering Gulma Golongan Teki}

Pada keseluruhan petak percobaan, gulma golongan teki yang dapat ditemukan adalah gulma Cyperus rotundus dan Cyperus iria. Pada 3 minggu setelah aplikasi (MSA ) bobot kering gulma teki pada Tabel 4 menunjukkan bahwa terjadi penekanan oleh herbisida atrazin dan mesotrion pada gulma yang tumbuh di petak perlakuan. Hal ini berarti tidak terjadi perbedaan penekanan pertumbuhan gulma pada semua dosis perlakuan herbisida, sedangkan pada 6 MSA keseluruhan perlakuan tidak dapat mengendalikan gulma golongan teki, hal ini diduga karena pada 6 MSA semua dosis herbisida hanya mampu menekan pertumbuhan gulma golongan daun lebar, sehingga gulma golongan teki tidak tertekan.

Tabel 4. Bobot kering gulma teki akibat perlakuan Herbisida Atrazin + Mesotrion

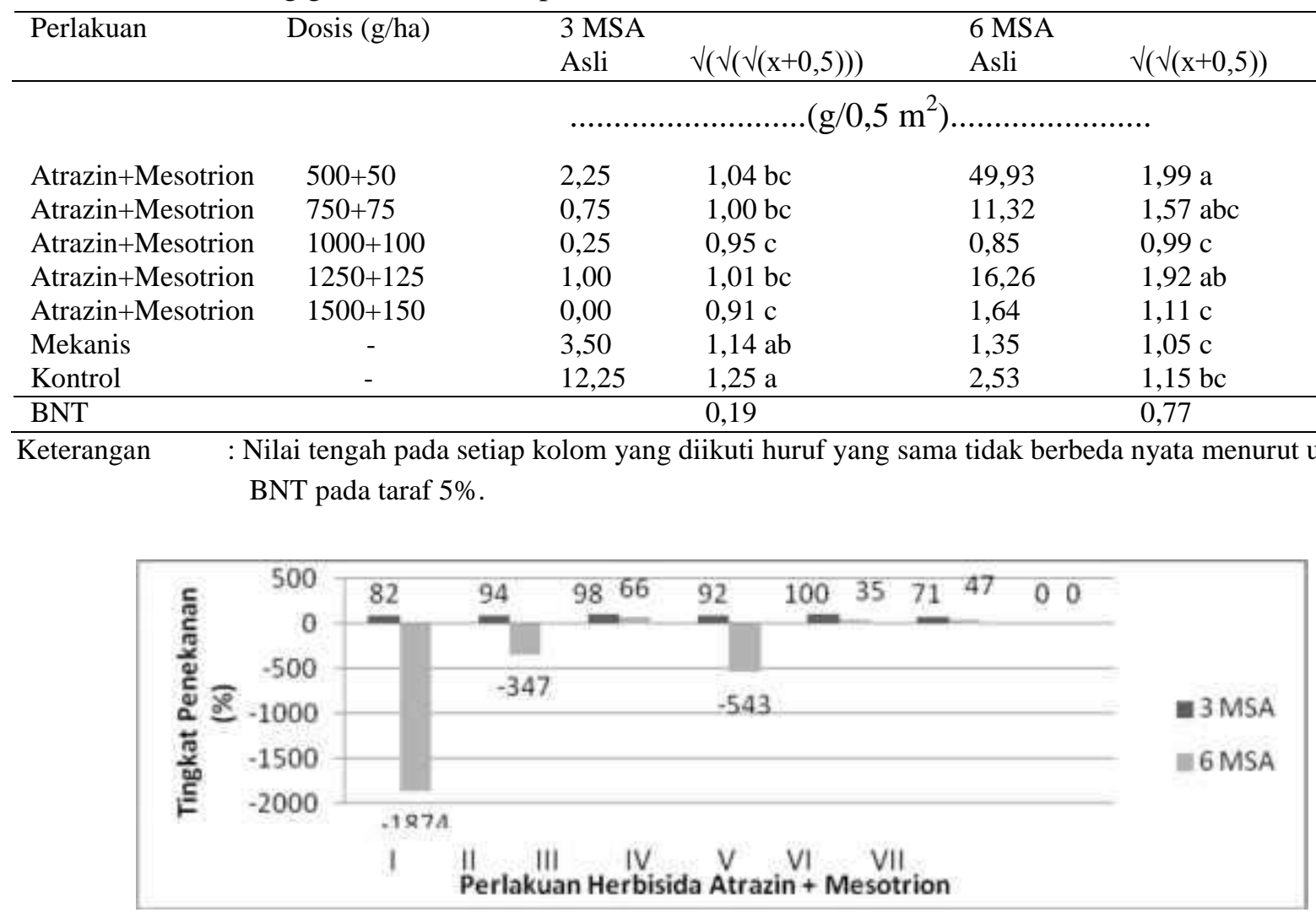

Gambar 4. Tingkat Penekanan Herbisida Atrazin+Mesotrion terhadap Gulma Golongan Teki
Keterangan : I :Atrazin 500g/ha+Mesotrion 50g/ha
VI : Mekanis
II : Atrazin 750g/ha+Mesotrion $75 \mathrm{~g} / \mathrm{ha}$
VII : Kontrol
III : Atrazin 1000g/ha+Mesotrion $100 \mathrm{~g} / \mathrm{ha}$
IV : Atrazin 1250g/ha+Mesotrion $125 \mathrm{~g} / \mathrm{ha}$
$\mathrm{V}$ : Atrazin $1500 \mathrm{~g} / \mathrm{ha}+$ Mesotrion $150 \mathrm{~g} / \mathrm{ha}$

Gambar 4 menunjukan pada 3 MSA tingkat penekanan tertinggi pada dosis $1500+150 \mathrm{~g} / \mathrm{ha}$ yang mampu menekan gulma sebesar $100 \%$, sedangkan pada 6 MSA tingkat penekanan tertinggi pada dosis $1000+100 \mathrm{~g} / \mathrm{ha}$ yaitu sebesar $66 \%$. 


\section{Bobot Pipilan Kering Jagung (Zea mays L.) pada KA $14 \%$}

Tabel 4 memperlihatkan bahwa tidak terdapat perbedaan antarperlakuan herbisida terhadap hasil pipilan kering jagung pada kadar air (KA) $14 \%$ hal ini di duga bahwa tanaman jagung merupakan tanaman $\mathrm{C} 4$ yang memiliki laju fotosintesis yang lebih tinggi daripada gulma, sehingga hasil pipilan kering tanaman jagung tidak terpengaruh oleh keberadaan gulma yang hadir di lahan budidaya. Ditambahkan oleh (Suparyono \& Setyono 1993 dalam Jamilah 2013) gulma tidak berpengaruh terhadap hasil pipilan kering jagung, namun gulma dapat menjadi inang beberapa hama dan penyakit, juga menyebabkan persaingan untuk mendapatkan unsur hara, air, ruang tempat tumbuh dan sinar matahari.

\section{Fitotoksitas Herbisida}

Berdasarkan hasil pengamatan secara visual pada minggu ke-1 dan ke-2 MSA menunjukkan bahwa tidak terdapat gejala keracunan pada tanaman jagung (Zea mays L.) pada petak perlakuan herbisida atrazin+mesotrion. Hal ini sejalan dengan hasil pengamatan tinggi tanaman, persen perkecambahan, dan hasil pipilan kering yang menunjukkan bahwa herbisida atrazin+mesotrion tidak mempengaruhi tanaman jagung. Seperti hasil penelitian Khan (2014) yang menunjukkan bahwa tidak terdapat gejala keracunan pada lahan tanaman jagung yang diaplikasi herbisida atrazin, baik tunggal maupun campuran.

\section{KESIMPULAN}

1. Herbisida atrazin dan mesotrion pada dosis $500+50 \mathrm{~g} / \mathrm{ha}$ hingga $1500+150 \mathrm{~g} / \mathrm{ha}$ dapat mengendalikan pertumbuhan gulma total, teki, Cyperus rotundus, dan Celosia argenthea pada 3 MSA, sedangkan pada 6 MSA tidak dapat mengendalikan gulma.

2. Herbisida atrazin dan mesotrion pada dosis $500+50 \mathrm{~g} /$ ha hingga $1500+150 \mathrm{~g} / \mathrm{ha}$ mampu mengendalikan gulma golongan daun lebar, Richardia brasiliensis dan Commelina benghalensis hingga 6 MSA.

3. Herbisida atrazin dan mesotrion pada dosis $500+50 \mathrm{~g} / \mathrm{ha}$ hingga $1500+150 \mathrm{~g} / \mathrm{ha}$ tidak mampu mengendalikan gulma golongan rumput, dan Rottboellia exaltata hingga 6 MSA

4. Herbisida atrazin dan mesotrion pada dosis $500+50 \mathrm{~g} / \mathrm{ha}$ hingga $1500+150 \mathrm{~g} /$ ha tidak mempengaruhi pertumbuhan dan produksi tanaman jagung (Zea mays L.).

\section{SARAN}

Diperlukan peneletian lebih lanjut tentang pengaruh dosis herbisida atrazin dan mesotrion terhadap tanaman selain jagung (Zea mays L).

\section{DAFTAR PUSTAKA}

Bilman, W.S. 2001. Pergeseran Komposisi Gulma Pada Beberapa Jarak Tanam Jagung dan Pengolahan Tanah. Jurnal Ilmu-Ilmu Pertanian Indonesia . 3 (1): 25-30.

Girsang, W. 2005. Pengaruh Tingkat Dosisi Herbisida Isopropilamina glifosat dan Selang Waktu Terjadinya Pencucian Setelah Aplikasi Terhadap Efektivitas Pengendalian Gulma Pada Perkebunan Karet (Hevea brasiliensis) TBM. Jurnal Penelitian Bidang Ilmu Pertanian. 3 ( 2) : 31-36.

Hasanudin. 2013. Aplikasi Beberapa Dosis Herbisida Campuran Atrazin dan Mesotrion pada Tanaman Jagung: Karakteristik Gulma. Jurnal Agrista. 17 (1) . 
Jamilah. 2013. Pengaruh penyiangan gulma dan sistem tanam terhadap pertumbuhan dan hasil tanaman padi sawah (Oriza sativa L). Jurnal Agrista . 17 (1)

Khan, H., K. B. Marwat, M. A. Khan, dan S. Hashim. 2014. Herbicidal Control of Parthenium Weed in Maize. Pakistan Journal of Botani. 46 (2) : 497 - 504.

Krisnamurti B. 2010. Manfaat Jagung dan Peran Produk Bioteknologi Serealia dalam Menghadapi Krisis Pangan, Pakan dan Energi di Indonesia. Prosiding Pekan Serealia Nasional

Mustajab, D.R.J. Sembodo, \& H. Hamim.2015. Efikasi Herbisida Atrazin terhadap Gulma Umum pada Lahan Budidaya Tanaman Jagung (Zea mays L.). Jurnal Penelitian Pertanian Terapan. 15 (1): 8-14

Solfiyeni, Chairul, \& R. Muharrami. 2013. Analisis Vegetasi Gulma Pada Pertanaman Jagung (Zea mays L.) di Lahan Kering dan Lahan Sawah di Kabupaten Pasaman. Prosiding Semirata FMIPA Universitas Lampung 